\title{
RECENSÃ 0
}

\section{Marilda L opes $G$ inez de L ara}

Professora doutora, U niversidade de São Paulo, Escola de C omunicações e A rtes, D epartamento de Biblioteconomia e D ocumentação

D O DEBEI, Vera Lucia D oyle. Tesauro: linguagem de representação da memória documentária. N iterói; Rio de Janeiro: Intertexto; Ed. Interciência, 2002.

U m dos grandes méritos do livro Tesauro, de Vera D odebei, em época na qual se experimenta euforia em relação à divulgação da informação em meios digitais, é enfatizar a necessidade da organização da informação como meio para socializar seu uso egerar conhecimento. Recuperando de Paul 0 tlet a idéia de desconstrução do texto para sua recuperação, a autora vê, na linguagem documentária, o instrumento formal que podereger tais reconstruções.

0 texto de $D$ odebei é dividido em duas partes: parte 1 , "Representação, memória e linguagem" (1.1 Representação documentária e 1.2 Linguagem documentária); parte 2, Construção deTesauro.

N a primeira parte, a representação documentária é discutida a partir da perspectiva de modelos, destacando os de caráter sistêmico, os mais utilizados para analisar as "memórias documentárias". Essa é uma perspectiva interessante, por constituir ponto de partida para a análise dos elementos, relações, processos e instrumentos envolvidos na elaboração de representações documentárias.

O modelo do "ciclo da informação" (ou detransferência da informação) foca os processos de produção, acumulação, uso de conhecimentos e produtos. À proposta original de L ancaster, a autora incorpora o conceito de "memória documentária" edivideo universo do conhecimento nos subconjuntos "informação" ( 0 universo das trocas de informação) e "documento" (universo das memórias documentárias). A análise do primeiro universo não se esgota na ciência da informação, alertando-se, entre outras coisas, para as alterações oriundas das mudanças paradigmáticas da ciência que implicam dificuldades na organização antecipada do conhecimento. Q uanto ao universo da memória documentária, as representações feitas pela "matriz documentária" (Wanderley, 1980) ou pelo modelo do Sistema de Recuperação da Informação (Montgomery, 1969) permitem isolar as etapas interdependentes do processo de representação.

D ado o tema central da obra, D odebei tece uma discussão detalhada sobre a representação da memória documentária, lembrando a complexidade do processo e recorrendo a autores dentro efora do âmbito da ciência da informação. Aponta para a não-homogeneidade de interpretação do conceito de representação ( ora ele é privilegiado, ora excluído como condição necessária do conhecer), mas concorda com as noções que vêem na representação a produção social do sentido, algo necessariamente parcial que pode variar segundo distintas abordagens e cuja existência completa só se realiza no indivíduo. 0 caráter social da representação introduz a discussão de conceitos como redução semântica, pluralidade de significados e produção de sentido que, interdependentes, remetem, na ciência da informação, aos atributos de funcionalidade eeconomia das representações: a produção do sentido éresultado deuma tensão necessária: "reduzir informação para obter conhecimento".

Ao analisar a disseminação dos produtos documentários, a autora levanta um aspecto interessante, privilegiando a diferença desse conceito relativamente aos de transmissão, divulgação ou veiculação pelo que relaciona as representações às necessidades do usuário. À maneira dos centros de cálculo de L atour (2000), a disseminação mobiliza associações entre documentos, dondeseu caráter de funcionar como filtro, atalho, de modo a poupar 0 usuário de uma oferta desmesurada de informações.

U m subcapítulo inteiro é dedicado à linguagem documentária. A autora aponta a heterogeneidade terminológica, remetendo suas prováveis causas às diferenças teórico-metodológicas entreo modelo europeu (que privilegia a analyse documentaire, portanto 0 processo) eo modelo americano (queutiliza a expressão genérica information indexing para todas as operações documentárias), às diferentes ênfases na abordagem da representação (no objeto de análise, nos processos, nos produtos, ou nos instrumentos de representação) eà escassez de reflexão teórica sobreessa questão, indicando a predominância, nos trabalhos brasileiros, de abordagens na intersecção lingüística e documentação.

Da observação das operações documentárias (e refletindo, de certo modo, a assimilação dos modelos sistêmicos), Dodebei constrói um quadro de sistematização que permite identificar o lugar ocupado pelas linguagens documentárias no espaço da representação. Apesar de utilizar o termo "linguagem de comunicação", a nosso ver redundante (a principal função da linguagem é a comunicação), o recurso utilizado pela autora pretende enfatizar essa capacidade nem sempre priorizada pela lingüística tradicional. 


\section{RECENSÃ 0}

Reconhece a função da linguagem documentária como meio de organização da memória documentária, fala de suas especificidades com relação à língua geral eintroduz, via U mberto $\mathrm{E} c 0$, conceitos semióticos úteis ao melhor entendimento das relações comunicativas. Ressalte-se, aqui, a exploração da noção de dicionário eenciclopédia associada aos conceitos de ordem/hierarquia edesordem/ rede, embora essa interpretação possa levar a certa confusão: a enciclopédia não significa necessariamente desordem, e o próprio autor a associa a rizoma (idéia originalmente enunciada por Deleuze), ou seja, ao contrário da linearidade do dicionário, a enciclopédia implica a possibilidade de múltiplas associações segundo pontos de partida distintos que, no entanto, só são concretizáveis sob a forma de dicionário, como exemplo de enciclopédias parciais. Sob nosso ponto de vista, a noção de enciclopédia serviria principalmente para falar das inúmeras possibilidades de organização das memórias documentárias.

As noções de hierarquia e rede, oriundas dos conceitos de dicionário e enciclopédia, respectivamente, constituem referência para a análise das linguagens documentárias, focando, no primeiro momento, o domínio; no segundo, o objeto; eno terceiro, a ordem. $\mathrm{N}$ o primeiro, são considerados os atributos tradicionais queseparam as linguagens documentárias pelo seu caráter universal ou especializado ( sistemas de classificação, listas de cabeçalhos de assunto), onde são privilegiadas as associações verticais (universo/ espécie, todo/ parte) e onde as associações não-lineares são raras, diferentemente do que ocorre com os tesauros e as classificações facetadas que tomam o conceito como unidadeestrutural. N o segundo momento, as linguagens documentárias são observadas a partir da prioridade dada à estruturação por conceitos, e não por assuntos: é o caso da proposta de Ranganathan, dos trabalhos do Classification Research G roup (classificações facetadas) e, contemporaneamente, dos estudos que optam (embora nem sempre, segundo nossa opinião) pela denominação "organização do conhecimento", cujas bases se assentam na Teoria G eral da Terminologia, de Wüster, e na Teoria do Conceito, deD ahlberg. Seas linguagens do primeiro momento são caracterizadas pela pré-coordenação, as do segundo o são pela pós-coordenação dos conceitos. No terceiro momento, a autora aponta para a necessidade de, ainda a partir do conceito, explorar com maior profundidade a noção de rede, partindo da segmentação do domínio de conhecimento de interesse. Embora essa seja uma idéia já presente, pelo menos embrionariamente, nas caracterizadas como de segundo momento (do nosso ponto de vista), o diferencial éa incorporação de elementos pragmáticos para orientar a construção dos roteiros situacionais que poderiam dar conta das especificidades do domínio visado.

As linguagens documentárias também são analisadas quanto às suas funções, destacando-se a comunicação entre informação documentária e usuário, para a qual é necessário combinar a garantia literária e garantia do usuário.

No segundo capítulo, a autora aborda especificamentea construção de tesauros. I dentifica origem do termo, fala deseu uso e detém-se na metodologia para sua construção e, citando experiência própria, enfatiza a importância do método que se apóia na garantia literária eno endosso do usuário para a coleta e definição dos termos.

U m subcapítulo é dedicado à organização de conceitos, partindo-se de sua conceituação filosófica, da exploração das abordagens dedutivas (dedução lógica) edepredicação conceitual (indução e dedução) para a formação de conceitos e também da análise das relações entre os conceitos e categorias. A importância dessa discussão está no fato de mostrar, com clareza, que a unidade informacional das linguagens documentárias não éa palavra, mas o conceito (de onde a importância da definição), base, também, para a organização formal do tesauro.

Pela sua abordagem diferenciada e pela forma como analisa a questão da representação e das linguagens documentárias, seguramente este é um livro que deve ser incorporado à bibliografia dos cursos de formação profissional em ciência da informação.

Recensão recebida em 24-06-2003 e aceita para publicação em 26-06-2003 